\title{
Hard times for marine sciences in Chile
}

\author{
Ruben Escribano $\cdot$ Serge A. Poulet
}

Received: 27 April 2010 / Accepted: 26 May 2010 / Published online: 19 June 2010

(C) Springer-Verlag 2010

The Department of Oceanography at the University of Concepción is part of the Faculty of Natural Sciences and Oceanography. For 30 years, the department has maintained a Marine Biological Station at Dichato, $40 \mathrm{~km}$ from the main campus, and a research vessel, Kay Kay II (20 m long and 47 gross tons). The UdeC-Dichato Unit is considered the centre of excellence for oceanography in Chile.

On February 27, 2010, a magnitude 8.8 earthquake struck the central region of Chile. The worst destruction occurred in the cities of Concepción, Talca, Talcahuano Harbour and Dichato, close to the epicentre. On the coast, the massive quake was followed by a highly destructive tsunami. Reports of these events have been made recently (Kaiser and Regalado 2010; Madariaga et al. 2010; Regalado 2010). Among Chilean scientific institutions and laboratories, the University of Concepión and the marine station were the worst hit, with the latter being almost totally destroyed.

Scientists have now evaluated the magnitude of the loss. Major damage and destruction has affected infrastructure (the vessel Kay Kay II, Marine Biological Station at Dichato, and main campus in Concepción), educational materials, valuable laboratory equipment and material, collections of scientific journals, archives, and irreplaceable samples. Loss estimates are around 7.5 million dollars US at UdeC-Dichato. For the entire country, the loss is about

Communicated by U. Sommer.

R. Escribano

COPAS Centre, Department of Oceanography,

University of Concepcion, Concepcion, Chile

S. A. Poulet $(\bowtie)$

Station Biologique de Roscoff, 29680 Roscoff, France

e-mail: poulet@sb-roscoff.fr
200 million dollars US to research facilities and equipment. The conclusion is that marine sciences and oceanography in Chile now face a major setback. Recovery of normal scientific and educational activities relies first on national political decisions. Scientists Unified for the Reconstruction of Chile, a lobbying group, will send a list of seven recommendations to Chile's minister of education to get research back to normal. The list includes additional grants for students whose projects are on hold and an emergency $\$ 90$ million line of credit so researchers can replace damaged equipment. In practice, the Chilean government is focused on restoring public infrastructure and helping the population, meaning that marine sciences might not be a high priority.

In the past 10 years, Chilean oceanographers established the Centre for Oceanographic Research in the eastern South Pacific (COPAS, Lange and Ulloa 2003), whose research activity has been primarily based at the Marine Biology Station at Dichato, and have achieved significant progress in understanding the Humboldt current system and the Oxygen Minimum Zone System (Morales and Lange 2004; Escribano and Schneider 2007; Ulloa and Pantoja 2009). The COPAS Centre (www.copas.cl) is devoted to advanced basic scientific research on the circulation, biogeochemical cycling, ecology, and paleoceanography of the eastern South Pacific Ocean. The objectives are to understand climate and ocean variability (present and past) and the impact on marine ecosystems and regional productivity. Multi- and interdisciplinary research covers diverse temporal and spatial scales and is based on observations, experiments, retrospective analysis, and modelling. This is done through six research programmes. Chile is considered a leader in marine sciences among South American countries. For instance, one of the major contributions of the COPAS Centre was the ongoing time series study off Concepción, 


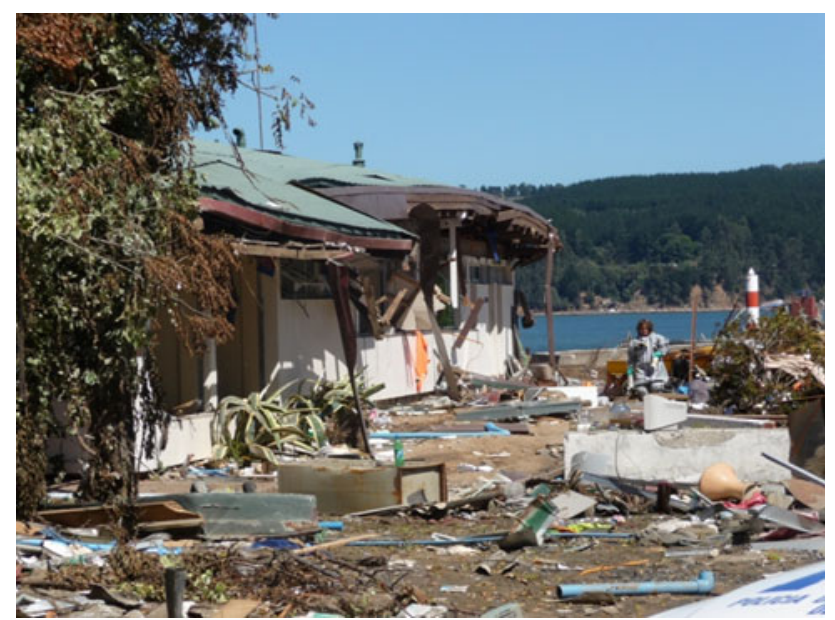

Fig. 1 Marine Station at Dichato, Chile, wrecked by tsunami in February, 2010 (photo from Dr. Camila Fernandez)

to assess oceanographic variability in the upwelling system of Central/Southern Chile (Escribano and Schneider 2007). It is likely that the earthquake and tsunami will seriously affect Chile's contributions to this data gathering for some time.

The UdeC-Dichato has played a key role in marine sciences education for about $60 \mathrm{PhD}$ and MSc students in oceanography from several Latin American countries in the past 20 years. In addition, a well-established Austral Summer Institute (ASI) has resulted in strong international collaboration in higher education in oceanography over the last 10 years. This ASI program was born in collaboration with the Woods Hole Oceanographic Institution 8 years ago and has promoted the development of advanced courses and lectures for Latin American students with participation by distinguished lecturers from several European countries, the USA, and Canada. All of these ASI activities were carried out at the Marine Biology Station at Dichato.

To get Chilean oceanographic research back on track will take time and probably will require international help. Chilean, American, and European researchers have developed a network of solidarity. Expected practical actions are (1) fundraising; (2) grant facilities for students to go abroad to resume their work; (3) shipping containers with scientific equipment and materials in response to Chilean priority needs. Delays in restoring marine sciences and oceanography may impair international cooperation, established in the past, between Chile and other countries.

To help Chilean marine scientist to get back to normal, contacts for information and fundraising are contacto @ anip.cl or rodor@oceanleadership.org (Fig. 1).

\section{References}

Escribano R, Schneider W (2007) The structure and functioning of the coastal upwelling system off central/south of Chile. Prog Oceanog 75:343-346

Kaiser J, Regalado A (2010) Chile's earthquake may set back research for years. Science 327:1308-1309

Lange C, Ulloa O (2003) Center for oceanographic research opens in Chile. EOS transactions. Am Geophy Union 84(7):61

Madariaga R, Métois M, Vigny C, Jaime Campos J (2010) Central Chile finally breaks. Science $328: 181-182$

Morales CE, Lange CB (eds) (2004) Oceanographic studies in the Humboldt current system off Chile: an introduction. Deep-Sea Res II 51:2345-2348

Regalado A (2010) Natural disasters: scientists count the costs of Chile's quake. Science 328:157

Ulloa O, Pantoja S (2009) The oxygen minimum zone of the eastern South Pacific. Deep- Sea Res II 56:987-991 